\title{
Transcription factor CREM coordinates the timing of hepatocyte proliferation in the regenerating liver
}

\section{Giuseppe Servillo, ${ }^{1}$ Maria Agnese Della Fazia, ${ }^{1}$ and Paolo Sassone-Corsi ${ }^{2}$}

Institut de Génétique et de Biologie M oléculaire et Cellulaire, Centre $\mathrm{N}$ ational de la Recherche Scientifique-Institut $N$ ational de la Santé et de la Recherche M édicale-Université Louis Pasteur (CNRS-IN SERM-ULP),

67404 Illkirch, Strasbourg, France

The liver regenerates upon partial hepatectomy (PH) as terminally differentiated hepatocytes undergo a tremendous proliferative process. CREM gene expression is powerfully induced during liver regeneration. We show that cell proliferation is significantly reduced upon $\mathrm{PH}$ in CREM $^{-1-}$ mice. There is a reduction in DNA synthesis, in the number of mitosis and of phosphorylated histone H3-positive cells. The post-PH proliferation peak is delayed by $10 \mathrm{hr}$, indicating an altered hepatocyte cell cycle Expression of cyclins A, B, D1, E, and cdc2, of c-fos and tyrosine aminotransferase is deregulated. CREM mutation results in delayed S-phase entry, impaining the synchronization of proliferation.

Received September 10, 1998; revised version accepted October 15, 1998.

The liver is one of the most important organs for homeostasis in mammals. Among its properties is the remarkable ability to regenerate following partial hepatectomy (Michalopoulos 1990; Fausto 1994). As much as $70 \%$ of the liver can be surgically removed and hepatocytes will proliferate to fully regenerate the original cell mass. The initial rounds of cell division are synchronous, and the first DN A replication occurs within $24 \mathrm{hr}$ of surgery in the rat. The regeneration process is completed within 10-15 days (Bucher 1963).

A number of hormones, growth factors, and cytokines and their coupled signal transduction pathways have been implicated in governing hepatocyte proliferation, but the precise orchestration of these factors is poorly understood (Diehl and Rai 1996; Michalopoulos and De Frances 1997). In particular, cytokines IL-6 and TNF have been implicated in initiating hepatocyte DNA synthesis during regeneration (Fausto et al. 1995; Cressman et al . 1996; Yamada et al . 1997), whereas the DN A-binding activity of the downstream transcription factors

${ }^{1}$ On leave from the Institute of General Pathology, University of Perugia, Policlinico Monteluce, Perugia, Ital y. These authors contributed equally to the work.

${ }^{2}$ Corresponding author.

E-MAIL paolosc@igbmc.u-strasbg.fr; FAX 33388653246.
Stat3 and N F-кB increases during the first hours following hepatectomy (Taub 1996).

A characteristic feature of liver regeneration is the dramatic increase in intracellular CAMP levels during the hepatocyte proliferation process, although its significance has remained elusive (Diehl et al. 1992). CAMP peaks during the first hours following partial hepatectomy, whereas elevated levels of CAMP also correlate with the proliferation of liver cell at birth (Diehl and Rai 1996). These notions underscore the critical role that must be played by CAM P-responsive transcription factors in liver regeneration.

Transcription factors coupled to CAMP signaling constitute a family of closely related bZIP proteins, either activators or repressors, binding to CAMP-responsive promoter elements (CREs) located within the regulatory regions of CAM P-inducible genes (Sassone-Corsi 1995; Montminy 1997). The factors CREB (CRE-binding protein), CREM (CRE modulator), and ATF-1 (activator transcription factor 1 ) are turned into activators by phosphorylation at a serine residue (Ser-133 in CREB; Ser-117 in CREM) (Gonzalez and M ontminy 1989; De Groot et al. 1993) elicited by PKA and other kinases (SassoneCorsi 1995; Montminy 1997). Interestingly, a CREB-like activity has been implicated in the transcriptional regulation of several liver-specific genes, such as tyrosine aminotransferase (TAT) (N ichols et al. 1992).

The CREM gene encodes both activators and repressors of CAMP-induced transcription (Foulkes et al. 1991a; Sassone-Corsi 1995). The repressor ICER (inducible cAMP early repressor) is generated by an intronic, CAM P-inducible promoter with kinetics of an early response gene (M olina et al. 1993; Stehle et al. 1993). Elevated ICER expression is characteristic of many neuroendocrine tissues (Stehle et al. 1993; Lalli and SassoneCorsi 1995; M onaco et al. 1995).

We have recently documented a powerful induction of ICER expression immediately following partial hepatectomy (Della Fazia et al. 1997; Servillo et al. 1997), which suggested that CREM gene products may play a role in the modul ation of gene expression by CAM P during liver regeneration. To address the precise function of CREM in the liver, we chose to study mice that we have generated carrying a targeted mutation in the CREM locus ( $N$ antel et al. 1996). Here we report that lack of CREM causes a 10-hr delay in the post-PH (partial hepatectomy) proliferation wave and deregulation in the expression of cyclins A, B, D1, E, and cdc2, as well as of c-fos and tyrosine aminotransferase (TAT). Thus, CREM appears to coordinate the timing of hepatocyte proliferation during the process of liver regeneration.

\section{Results and Discussion}

Delayed hepatocyte proliferation in CREM-deficient mice

To address the precise function of CREM in the liver, we have generated mice that carry a targeted mutation in 
the CREM locus (N antel et al. 1996). We performed PH on CREM mutants and wild-type littermates to compare subsequent liver regeneration. The first round of DN A synthesis in the regenerating liver was anal yzed by measuring $\left[{ }^{3} \mathrm{H}\right]$ thymi dine incorporation (Fig. 1A). U ntil 34-hr after $\mathrm{PH}$, both wild-type and $\mathrm{CREM}^{-1}$ - animals showed comparable, low levels of incorporation, equival ent to control animals. DN A synthesis peaks in wild-type animals at $38 \mathrm{hr}$ after $\mathrm{PH}$, as reported previously (Yamada et al. 1997). Strikingly, the 38-hr peak is absent in CREM deficient mice (Fig. 1A). Incorporation in wild-type animals decreases progressively after the 38-hr peak. The profile in CREM ${ }^{-1-}$ mice is remarkably different. A modest rise in incorporation is seen at $48 \mathrm{hr}$ following $\mathrm{PH}$, with a 10-hr delay compared to the peak in wild-type littermates (Fig. 1A).

A utoradiographic analysis of histological liver sections from operated animals reveal ed significant differences between wild-type and CREM mutant mice (Figs. $1 B$ and 2). Variations in the number of label ed hepatocyte nuclei parallel the kinetics of $\left[{ }^{3} \mathrm{H}\right]$ thymidine incorporation. In wild-type mice, val ues peak at $38 \mathrm{hr}$ after $\mathrm{PH}$, to return at pre-PH levels by $72 \mathrm{hr}$. In sharp contrast, very few labeled nuclei are detected at $38 \mathrm{hr}$ in CREM $-1-$ mice, where a 10-hr-del ayed, reduced peak is observed at $48 \mathrm{hr}$ (Fig. 1B). A comparison of the nuclei at peak times reveals that the labeling is much stronger in wild-type mice than in mutants (Fig. 2). Histological inspection of mitotic figures during liver regeneration (Fig. 1C) is consistent with the timing of DNA synthesis.

\section{Changes in gene expression}

Mitotic waves are characterized by a cyclic, highly specific phosphorylation of histone $\mathrm{H} 3$, which is thought to represent a key step in chromatin remodeling during the cell division (Hendzel et al. 1997). We have used antibodies that specifically recognize the phosphorylated form of histone H3 (phospho-H3) and that specifically label mitotic nuclei (Fig. 3A). A comparison between the number of phospho-H3-positive nuclei at $48 \mathrm{hr}$ posthepatectomy revealead a significant decrease in CREM-deficient mice as compared to wild-type littermates (Fig. 3B).

Histological comparative analysis 15 days after $\mathrm{PH}$ of wild-type and CREM ${ }^{-1-}$ mice of regenerated hepatic tissue showed no significant difference between the two groups (not shown). Similarly, level s of IL-6 and TN F $\alpha$, both having a critical role in liver regeneration (Cressman et al. 1996; Yamada et al. 1997), are al so similar during the first $48 \mathrm{hr}$ after $\mathrm{PH}$ (not shown). Thus, the CREM mutant animals demonstrate a significant delay in the timing of the first wave of DNA synthesis that follows $\mathrm{PH}$, whereas hepatocyte morphology and the subsequent regeneration of the tissue appear normal.

Expression of genes involved in glucogenesis, such as TAT and phoshoenol pyruvate carboxykinase (PEPCK), is known to be induced in the liver during the first hours after PH (Mohn et al. 1990; Della Fazia et al. 1992). Kinetics of TAT expression following PH is similar in both wild-type and mutant mice, but the peak level in the $\mathrm{CREM}^{-1-}$ mice is significantly lower than in the wild type. An equivalent effect is observed on PEPCK (Fig. 4A). Thus, whereas CREM mutation leads to a significant delay in the first wave of hepatocyte division (Figs. 1 and 2), not the timing, but the amplitude of the early TAT and PEPCK induction is significantly affected. This effect is compatible with the presence of CREs within the TAT and PEPCK promoters and their responsi veness to CAMP (N ichols et al. 1992).

Induction of the early response gene $\mathrm{c}$-fos upon $\mathrm{PH}$ has been well documented (M ohn et al. 1990). We observe that the kinetics of c-fos inducibility upon $\mathrm{PH}$ in $\mathrm{CREM}^{-1-}$ mice is altered, as the transcriptional attenuation that follows the peak of inducibility is diminished (Fig. 4). This observation supports a scenario in which CREM contributes to the transcriptional attenuation of CAM P-induced genes (Foulkes et al. 1991b; Lamas et al. 1997). Importantly, the kinetics of fra-2 inducibility are identical in wild-type and mutant animals (Fig. 4B). Constitutive CREB expression is not altered during liver re-
A

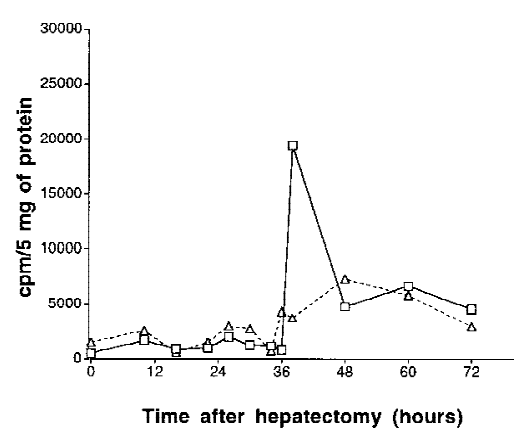

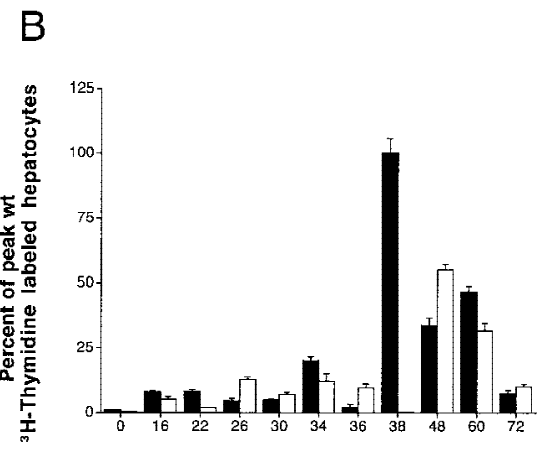

Time after hepatectomy (hours)

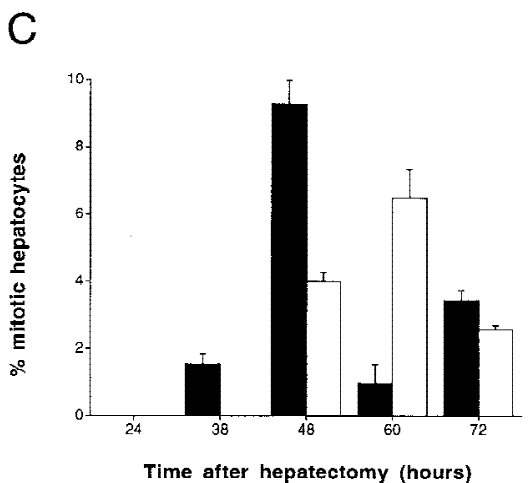

Figure 1. Delayed peak of hepatocyte proliferation in CREM-deficient mice. (A) Kinetics of $\left[{ }^{3} \mathrm{H}\right]$ thymidine incorporation into DNA during wild-type $(\square)$ and CREM ${ }^{-1-}(\triangle)$ liver regeneration (0-72 hr after $\mathrm{PH}$ ). $\left.{ }^{3} \mathrm{H}\right]$ Thymidine incorporation was determined using scintillation counting and expressed as counts/min/5 mg of protein. (B) Percentage of positive dark-stained hepatocyte nuclei during $\left[{ }^{3} \mathrm{H}\right]$ thymidine incorporation. The time point with highest incorporation (38 hr in wild type) was considered $100 \%$ with respect to the other time points. (C) Mitotic figures in hepatocytes were counted and quantitated as a percentage of the total number of hepatocytes in 10 high-power fields by two investigators at the indicated times after PH. (B,C) ( $\square$ Wild type; $\square$ CREM ${ }^{-1} \rightarrow$ S.E.M. is shown. 


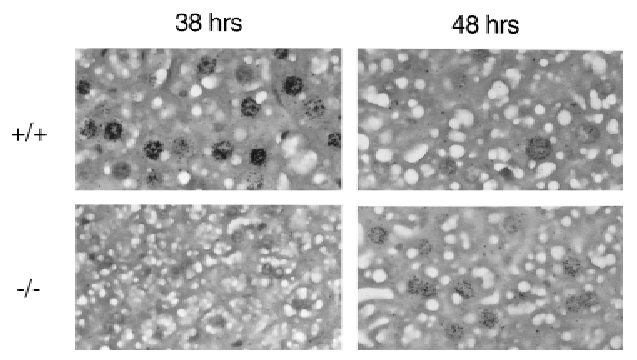

Figure 2. Histological analysis of labeled nuclei during liver regeneration. Autoradiography shows positive hepatocyte nuclei in wild-type $(t+)$ and mutant $(-t \rightarrow$ animals. Intensity is proportional to the relative levels of $\left[{ }^{3} \mathrm{H}\right]$ thymidine incorporation.

generation, and there is no significant difference between mutant and wild-type mice (Fig. 4A). A similar situation was observed for ATF-1 (not shown). ATF-3, a CAM P-unresponsiveCRE-binding protein (Sassone-Corsi 1995), has been documented to be induced upon PH with the kinetics of an early response gene (Chen et al. 1996). ATF-3 expression is equival ent in wild-type and CREM deficient animals (Fig. 4A). These results indicate that there are no major alterations in the expression of other CRE-binding factors in the liver of CREM mutant mice.

\section{Deregulation of cyclins}

The coordinated rounds of cell division following $\mathrm{PH}$ constitute an in vivo system to study the role played by cyclins at specific checkpoints of the cell cycle (Reed 1991; Pines 1994; Sherr 1994). The expression of cyclins in the regenerating liver has been studied extensively ( $\mathrm{Lu}$ et al. 1992; Albrecht et al. 1993; Loyer et al. 1994; Michal opoulos and De Frances 1997). The del ay in hepatocyte proliferation seen in CREM-deficient mice (Fig. 1) and the direct regulation of cyclin A expression by CREM (Desdouets et al. 1995; Lamas et al. 1997)

(A)

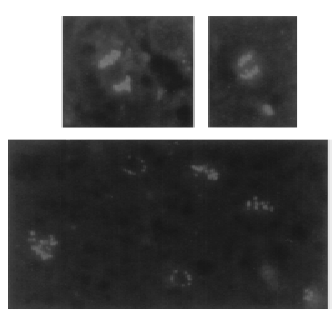

(B)

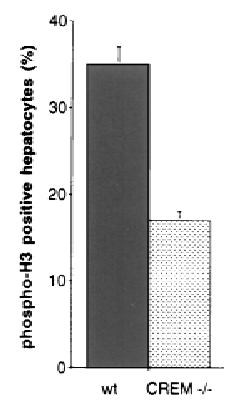

Figure 3. Labeling of hepatocytes showing phospho- $\mathrm{H} 3$ at 48 hr after PH. (A) Representative micrographs of mitotic figures (top panels) and label ed nuclei (bottom panel) designating phospho-H3-positive cells visible during liver regeneration. (B) N umber of phospho-H3-positive hepatocytes observed at $48 \mathrm{hr}$ after PH. Values are shown (S.E.M.) collected over 20 fields of observations.
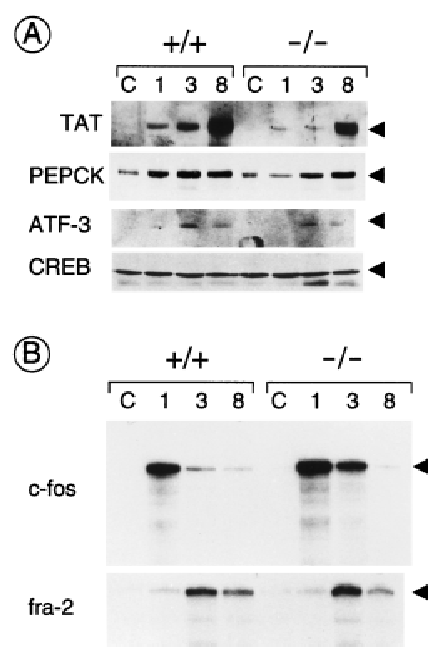

Figure 4. Gene expression in the first hours of liver regeneration after PH. (A) Western blot analysis using anti-TAT and anti-PEPCK antibodies of mice liver extracts from animals at various times after $\mathrm{PH}(1,3$, and $8 \mathrm{hr})$. Western blot analysis of lysates using an anti-CREB antibody confirms that the same amount of total protein has been loaded in each lane (bottom panel). (B) RN ase protection analysis of c-fos and fra-2 expression using total RNA from regenerating liver at various times after $\mathrm{PH}(1,3$, and $8 \mathrm{hr})$. This experiment was performed several times with consistent results. Expression of c-fos at the $3 \mathrm{hr}$ time point is fivefold higher $( \pm 0.5)$ in CREM mutant mice vs. wild type, as establ ished after scanning various autoradi ographs.

prompted us to analyze the expression of cyclins A, B, D1, E, and cdc2 following PH. Cyclin A expression is undetectable in normal liver or during the $\mathrm{G}_{1}$ phase; it is strongly induced during the hepatocyte $\mathrm{S}$ phase and decreases to normal levels 3 days after PH (Verges et al. 1997). Expression of cyclin A increases rapidly at $38 \mathrm{hr}$ after $\mathrm{PH}$ in wild-type mice, corresponding to the peak of $\left[{ }^{3} \mathrm{H}\right]$ thymidine incorporation, to then decrease progressively. In CREM-deficient mice the peak of cyclin A is delayed until $48 \mathrm{hr}$ following $\mathrm{PH}$ and is significantly lower than in wild-type animals (Fig. 5). A similar situ-

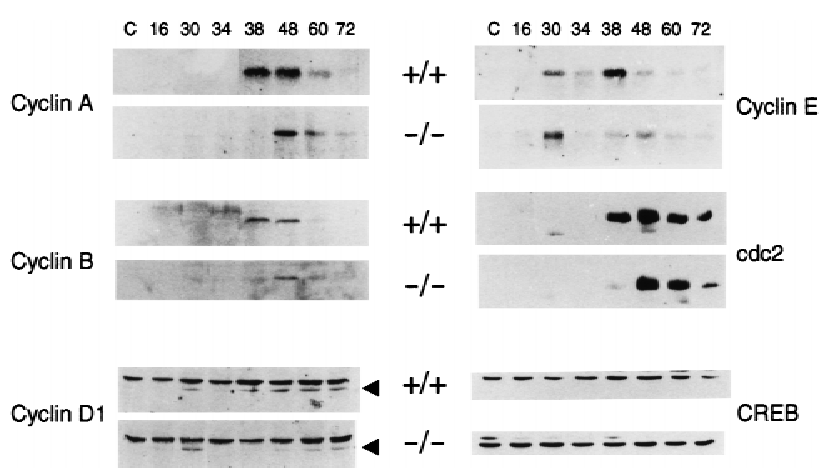

Figure 5. A berrant cyclin expression in the regenerating liver of CREM-deficient mice. Western blot analysis of mice liver extracts at different times after $\mathrm{PH}$ (hours) using antibodies against cyclins A, B1, D1, E, and cdc2. Analysis using an antiCREB antibody shows that the same amount of total protein is loaded in each lane. 
ation is observed for cyclin B (Trembley et al. 1994), whose peak of expression is delayed and reduced in CREM mutant mice (Fig. 5). Cyclin D1 rise in expression is known to occur $38 \mathrm{hr}$ after $\mathrm{PH}$ during the hepatocyte S phase and to persist until $72 \mathrm{hr}$ (Albrecht et al. 1995). In CREM mutant mice the rise in expression is delayed to $48 \mathrm{hr}$, with levels much lower than the wild-type animal (Fig. 5). Cyclin E shows two peaks of expression in normal mice, at 30 and $38 \mathrm{hr}$. In CREM mutant mice the 30-hr peak is conserved, whereas the 38-hr peak is delayed and weakened (Fig. 5). Finally, expression of cdc2 is also al tered drastically in CREM-deficient mice. The rise in cdc2 levels is again delayed as compared to wild-type mice (Fig. 5). Together, these results are consistent with the notion that in CREM mutant animals the cell cycle progresses normally through $\mathrm{G}_{1}$ phase but that the entry into $S$ phase is delayed, causing a desynchronization in proliferation.

\section{Conclusion}

Our results address the role of a CAM P-responsive transcription factor in a cellular prol iferation process in vivo. Liver regeneration following $\mathrm{PH}$ has proved a powerful model system to understand the signals initiating and controlling cellular proliferation. CAMP fluxes are well documented to accompany the first rounds of hepatocyte cell division (Diehl et al. 1992; Della Fazia et al. 1997), but the cellular mechanism by which this second messenger operates has remained el usive. The powerful induction in CREM expression following hepatectomy that we have documented recently (Servillo et al. 1997) suggests that it may play an important regulatory role. The results reported here provide evidence that this CAM P-responsive transcription factor acts as a nuclear effector in regulating hepatocyte proliferation. Loss of CREM function results in a significant delay in the first round of mitosis. The inherent synchronization of the first round of cell division upon $\mathrm{PH}$ reveals that CREM is involved in the entry into $S$ phase. Expression of TAT, PEPCK, and c-fos is affected, whereas drastic changes in the levels of cyclins point to a normal passage of the hepatocytes through the $G_{1}$ phase but an altered synchronization of cells undergoing division and a remarkable delay in the entry into S phase. It is interesting to note that TAT, PEPCK, c-fos and several cyclin genes contain CRE elements within their promoter regulatory regions. This notion and the results reported here place CREM in a central position in the orchestration of the molecular events regul ating hepatocyte prol iferation and cell cycle during the process of liver regeneration.

\section{Materials and methods}

Animals

The generation of CREM ${ }^{-1-}$ mice has been described previously. The mutagenesis of the CREM locus was designed to abolish the generation of all isoforms encoding transcriptional activators and repressors ( $\mathrm{N}$ antel et al. 1996). The CREM ${ }^{-1-}$ animals and wild-type controls were maintained in a 12:12-hr light/dark cycle, and food and water were provided ad libitum. Adult mice (25-32 grams) were used for PH. Liver resection of the left lateral and median lobes was performed after a midventral laparatomy (Higgins and Anderson 1931). Surgery was performed between 8 a.m. and 12 a.m. under ether anesthesia. The mortality of the animals following PH was $<5 \%$. Liver tissue was rinsed in situ with PBS by perfusion through the portal vein for $10 \mathrm{sec}$ to eliminate blood cells. Livers were then minced and divided into al iquots for further processing. Four wild-type and CREM ${ }^{-1-}$ ani mals were analyzed for each time point, and experiments were repeated at least three times.

$\left.{ }^{3} \mathrm{H}\right]$ Thymidine incorporation

$\left[{ }^{3} \mathrm{H}\right.$ T hymidine (N EN, DuPont $15 \mathrm{mCi} / \mathrm{mmole}$ ) was injected intraperitoneally $2 \mathrm{hr}$ before sacrifice $(0.5 \mu \mathrm{Ci} / \mathrm{gram}$ of body weight). Biopsies were homogenized in PBS by sonication to a final concentration of $40 \mathrm{mg} / \mathrm{ml}$ tissue. Aliquots of each sample were used for protein determination (BioRad). Incorporation of $\left[{ }^{3} \mathrm{H}\right]$ thymidine into de novo synthesized DNA was assayed by precipitation of nucleic acid with TCA and successive washes with 10\% and 5\% TCA (Loyer et al. 1994). DN A synthesis was expressed as counts per minute in 5-mg aliquots of protein.

Histological and autoradiographic analyses

Fragments of liver were fixed immediately in Bouin's solution. After 2 days, fixed tissues were embedded in paraffin, and 5- $\mu \mathrm{m}$ slices were microtome sectioned and mounted on slides. For histological analysis sections were stained with hematoxylin-eosin; for autoradiographic analysis sections were unstained. Mitotic figures in hepatocytes were counted in 10 high-power fields and expressed as a percentage of the total number of hepatocytes by two investigators. The slides for autoradiographic analysis were coated in NTB-2 emulsion and than stored in the dark at $4^{\circ} \mathrm{C}$. After 28 days the slides were developed and counterstained with hematoxylin-eosin. Analysis of $\left[{ }^{3} \mathrm{H}\right]$ thymidine incorporation was performed by counting positive dark-staining hepatocyte nuclei on each slide in 10 low-power fields. Histological analysis of nuclei positive for the phosphorylated form of histone $\mathrm{H} 3$ was performed as described (Hendzel et al. 1997). Anti phospho-H3 antibodies were a generous gift of Dr. C.D. Allis (University of Virginia, Charlottesville).

RNA analysis

Liver RNA was obtained by homogenizing the tissue in guanidinium thiocyanate solution followed by $\mathrm{CsCl}$ step gradient centrifugation. Approximately $20 \mu \mathrm{g}$ of liver RN A was analyzed by RN ase protection using c-fos and fra-2 riboprobes. The c-fos riboprobe encompasses the first exon of the specific mRNA; the fra-2 riboprobe has been described previously (Foulkes et al. 1996). RN ase protection analyses were performed several times with consistent results.

Immunoblot analysis

Liver tissue was homogenized in Laemmli sample buffer, boiled, and sonicated. Protein extracts were normalized by SDS-PAGE followed by Coomassie blue staining. Subsequently, liver extracts were analyzed by Western blot using specific antibodies and then visualized by ECL chemiluminescence (Amersham). Anti-TAT and anti-PEPCK polyclonal antibodies were a kind gift of Dr. D.K. Granner (Vanderbilt University, N ashville, TN ); antibodies against ATF-3, cyclins A, B1, D1, E, and cdc2 were purchased from Santa Cruz Biotechnology; the anti-CREB polyclonal antibody was obtained from Bio-Labs.

\section{Acknowledgments}

We are grateful to C.D. Allis for the generous gift of the anti-phospho-H3 antibodies. We thank D.K. Granner, N. Fausto, G.M. Fimia, C.D. Allis, M. Viola-M agni, and all the members of the Sassone-Corsi laboratory for help, discussions, and gifts of material. We are grateful for the excellent technical assistance of G. Duval, E. Heitz, and B. Boulay. G.S. is supported by fellowships from Fondation de la Recherche M édicale (France) and the Consigl io $\mathrm{N}$ azionale del le Ricerche (Italy). M .A.D.F. is supported by IN SERM. This work was supported by grants from CN RS, IN SERM, Hôpital Universitaire de Strasbourg, Fondation de la Recherche M édicale, ULP, and Association pour la Recherche sur le Cancer.

The publication costs of this article were defrayed in part by payment of page charges. This article must therefore be hereby marked 'advertisement' in accordance with 18 USC section 1734 solely to indicate this fact. 


\section{References}

Albrecht, J.H., J.S. Hoffman, B.T. Kren, and C.J. Steer. 1993. Cyclin and cyclin-dependent kinase 1 mRNA expression in models of regenerating liver and human liver diseases. Am. J. Physiol. 265: G857G864.

Albrecht, J.H., M.Y. Hu, and F.B. Cerra. 1995. Distinct patterns of cyclin D1 regulation in models of liver regeneration and human liver. Biochem. Biophys. Res. Commun. 209: 648-655.

Bucher, N.L.R. 1963. Regeneration of mammalian liver. Int. Rev. Cytol. 15: $245-300$.

Chen, B.P., C.D. Wolfgang, and T. Hai. 1996. Analysis of ATF3, a transcription factor induced by physiological stresses and modulated by gadd153/Chop10. Mol. Cell. Biol. 16: 1157-1168.

Cressman, D.E., L.E. Greenbaum, R.A. De Angelis, G. Ciliberto, E.E. Furth, V. Poli, and R. Taub. 1996. Liver failure and defective hepatocyte regeneration in interleukin-6-deficient mice. Science 274: 13791383.

De Groot, R.P., J. den Hertog, J.R. Vandenheede, J. Goris, and P. SassoneCorsi. 1993. Multiple and cooperative phosphorylation events regulate the CREM activator function. EMBO J. 12: 3903-3911.

Della Fazia, M.A., G. Servillo, and M. Viola M agni. 1992. Different expression of tyrosine aminotransferase and serine deydratase in rat livers after partial hepatectomy. Biochem. Biophys. Res. Commun. 182: 753-759.

Della Fazia, M.A., G. Servillo, and P. Sassone-Corsi. 1997. Cyclic AM P signalling and cellular proliferation: Regulation of CREB and CREM . FEBS Lett. 410: 22-24.

Desdouets, C., G. M atesic, C. Molina, N .S. Foulkes, P. Sassone-Corsi, C. Brechot, and J. Sobczak-Thepot. 1995. Cell cycle regulation of cyclin A gene expression by the cyclic AM P-responsive transcription factors CREB and CREM. Mol. Cell. Biol. 15: 3301-3309.

Diehl, A.M . and R.M. Rai. 1996. Regulation of signal transduction during liver regeneration. FASEB J. 10: 215-227.

Diehl, A.M., S.Q. Yang, D. Wolfgang, and G. Wand. 1992. Differential expression of guanine nucleotide-binding proteins enhances CAMP synthesis in regenerating rat liver. J. Clin. Invest. 89: 1706-1712.

Fausto, N. 1994. Liver regeneration. In The liver: Biology and pathobiol ogy (ed. I.M. Arias, J.L. Boyer, W.B. Jakoby, N . Fausto, D. Schachter, and D.A. Shafritz), pp. 1059-1084. Raven Press, N ew York, NY.

Fausto, N ., A.D. Laird, and E.M . Webber. 1995. Role of growth factors and cytokines in hepatic regeneration. FASEB J. 9: 1527-1536.

Foulkes, N.S., E. Borrelli, and P. Sassone-Corsi. 1991a. CREM gene: Use of alternative DNA-binding domains generates multiple antagonists of cAMP-induced transcription. Cell 64: 739-749.

Foulkes, N.S., B. Laoide, F. Schlotter, and P. Sassone-Corsi . 1991b. Transcriptional antagonist CREM down-regulates C-fos CAM P-induced expression. Proc. Natl. Acad. Sci. 88: 5448-5452.

Foulkes, N.S., J. Borjigin, S.H. Snyder, and P. Sassone-Corsi . 1996. Transcriptional control of circadian hormone synthesis via the CREM feedback loop. Proc. Natl. Acad. Sci. 93: 14140-14145.

Gonzalez, G.A. and M.R. Montminy. 1989. Cyclic AMP stimulates somatostatin gene transcription by phosphorylation of CREB at Ser133. Cell 59: 675-680.

Hendzel, M.J., Y. Wei, M.A. Mancini, A. Van Hooser, T. Ranalli, B.R. Brinkley, D.P. Bazett Jones, and C.D. Allis. 1997. Mitosis-specific phosphorylation of histone $\mathrm{H} 3$ initiates primarily within pericentromeric heterochromatin during $\mathrm{G} 2$ and spreads in an ordered fashion coincident with mitotic chromosome condensation. Chromosoma 106: 348-360.

Higgins, G.M and R.M. Anderson. 1931. Experimental pathology of liver: Restoration of liver in white rat following partial surgical removal. Arch. Pathology 12: 186-202.

Lalli, E. and P. Sassone-Corsi. 1995. Thyroid-stimulating hormone (TSH)directed induction of the CREM gene in the thyroid gland participates in the long-term desensitization of the TSH receptor. Proc. Natl. Acad. Sci. 92: 9633-9637.

Lamas, M., C. Molina, N.S. Foulkes, E. Jansen, and P. Sassone-Corsi. 1997. Ectopic ICER expression in pituitary corticotroph AtT20 cells: Effects on morphology, cell cycle, and hormonal production. Mol. Endocrinol. 11: 1425-1434.

Loyer, P., D. Glaise, S. Cariou, G. Baffet, L. Meijer, and C. GuguenGuillouzo. 1994. Expression and activation of cdks (1 and 2) and cyclins in the cell cycle progression during liver regeneration. J. Biol. Chem. 269: 2491-500.

Lu, X.P., K.S. Koch, D.J. Lew, V. Dulic, J. Pines, S.I. Reed, T. Hunter, and H.L. Leffert. 1992. Induction of cyclin mRNA and cyclin-associated histone $\mathrm{H} 1$ kinase during liver regeneration. J. Biol. Chem. 267: 2841-2844

Michal opoul os, G.K. 1990. Liver regeneration: Molecular mechanisms of growth control. FASEB J. 4: 176-187.

Michalopoulos, G.K. and M. De Frances. 1997. Liver regeneration. Science 276: 60-66.

Mohn, K.L., T.M. Laz, A.E. M el by, and R. Taub. 1990. Immediate-early gene expression differs between regenerating liver, insulin-stimulated $\mathrm{H}-35$ cells, and mitogen-stimulated Balb/c 3T 3 cells. Liver-specific induction patterns of gene 33, phosphoenol pyruvate carboxykinase, and the jun, fos, and egr families. J. Biol. Chem. 265: 2191421921.

Molina, C., N.S. Foulkes, E. Lalli, and P. Sassone-Corsi. 1993. Inducibility and negative autoregulation of CREM : An alternative promoter directs the expression of ICER, an early response repressor. Cell 75: 875-886.

Monaco, L., N.S. Foulkes, and P. Sassone-Corsi. 1995. Pituitary folliclestimulating hormone (FSH) induces CREM gene expression in Sertoli cells: Involvement in long-term desensitization of the FSH receptor. Proc. Natl. Acad. Sci. 92: 10673-10677.

Montminy, M.R. 1997. Transcriptional regulation by cyclic AM P. Annu. Rev. Biochem. 66: 807-822.

Nantel, F., L. Monaco, N.S. Foulkes, D. Masquilier, M. Le Meur, K. Henriksen, A. Dierich, M. Parvinen, and P. Sassone-Corsi . 1996. Spermiogenesis deficiency and germ-cell apoptosis in CREM-mutant mice. Nature 380: 159-162.

Nichols, M., F. Weih, W. Schmid, C. De Vack, E. Kowenz-Leutz, B. Luckow, M. Boshart, and G. Schutz. 1992. Phosphorylation of CREB affects its binding to high and low affinity sites: implications for CAMP induced gene transcription. EMBO J. 11: 3337-3346.

Pines, J. 1994. The cell cycle kinases. Semin. Cancer Biol. 5: 305-313.

Reed, S.I. 1991. G1-specific cyclins: In search of an S-phase promoting factor. Trends Genet. 7: 95-99.

Sassone-Corsi, P. 1995. Transcription factors responsive to CAM P. Annu. Rev. Cell. Dev. Biol. 11: 355-377.

Servillo, G., L. Penna, N.S. Foulkes, M. Viola Magni, M.A. Della Fazia, and P. Sassone-Corsi. 1997. Cyclic AM P signalling pathway and celIular proliferation: Induction of CREM during liver regeneration. O ncogene 14: 1601-1606.

Sherr, C.J. 1994. G1 phase progression: Cycling on cue. Cell 79: 551-555.

Stehle, J.H., N.S. Foulkes, C. Molina, V. Simonneaux, P. Pevet, and P. Sassone-Corsi. 1993. Adrenergic signals direct rhythmic expression of transcriptional repressor CREM in the pineal gland. Nature 365: 314-320.

Taub, R. 1996. Transcriptional control of liver regeneration. FASEB J. 10: 413-427.

Trembley, J.H., B.T. Kren, and C.J. Steer. 1994. Posttranscriptional regulation of cyclin B messenger RNA expression in the regenerating rat liver. Cell. Growth Differ. 5: 99-108.

Verges, M., A. Castro, M. Jaumot, O. Bachs, and C. Enrich. 1997. Cyclin $A$ is present in the endocytic compartment of rat liver cells and increases during liver regeneration. Biochem. Biophys. Res. Commun. 230: 49-53.

Yamada, Y., I. Kirillova, J.J. Peschon, and N. Fausto. 1997. Initiation of liver growth by tumor necrosis factor: Deficient liver regeneration in mice lacking type I tumor necrosis factor receptor. Proc. Natl. Acad. Sci. 94: 1441-1446. 


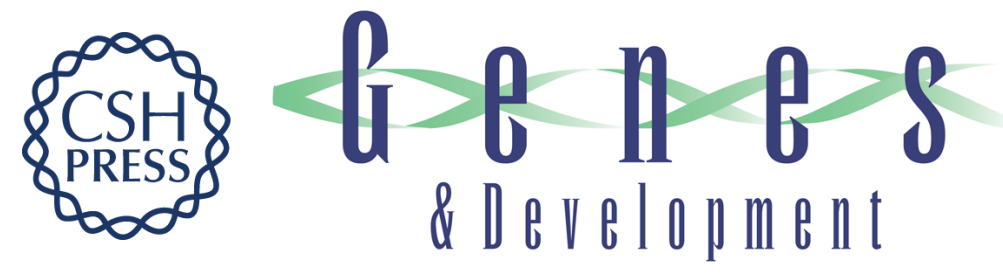

\section{Transcription factor CREM coordinates the timing of hepatocyte proliferation in the regenerating liver}

Giuseppe Servillo, Maria Agnese Della Fazia and Paolo Sassone-Corsi

Genes Dev. 1998, 12:

Access the most recent version at doi:10.1101/gad.12.23.3639

References This article cites 38 articles, 13 of which can be accessed free at: http://genesdev.cshlp.org/content/12/23/3639.full.html\#ref-list-1

License

Email Alerting Receive free email alerts when new articles cite this article - sign up in the box at the top Service right corner of the article or click here.

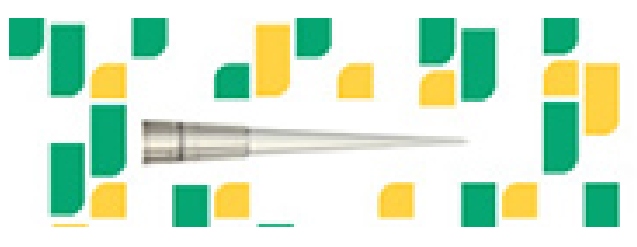

Focused on your science. 